\title{
SHIFTING ISLAMIC EDUCATION PARADIGM ON LAMPUNG TRADITION COMMUNITY
}

\author{
Ahmad Muzakki \\ State Islamic Institute (IAIN) Metro \\ East Metro, Metro, Lampung, 34112, Indonesia \\ E-mail:am.zakki@yahoo.co.id \\ Dedi Wahyudi \\ State Islamic Institute (IAIN) Metro \\ East Metro, Metro, Lampung, 34112, Indonesia \\ E-mail:podoluhur91@gmail.com

\section{Zuhairi} \\ State Islamic Institute (IAIN) Metro \\ East Metro, Metro, Lampung, 34112, Indonesia \\ E-mail: zuhairistain@gmail.com
}

\begin{tabular}{c|c|c}
\hline Received: & Revised: & Approved: \\
27/03/2019 & $12 / 04 / 2019$ & $17 / 06 / 2019$ \\
\hline
\end{tabular}

DOI: http://dx.doi.org/10.32332/akademika.v24i1.1616

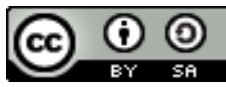

Shifting Islamic Education Paradigm On Lampung Tradition Community Licensed Under a Creative Commons Attribution-ShareAlike 4.0

International License

\begin{abstract}
This article presents the results of research on the "new direction" of Islamic education in Lampung: reading the shifting paradigm of Islamic education to Lampung indigenous people. The purpose of this study is to describe the paradigm shifting process of Islamic education within Lampung indigenous people. The research data were collected through interviews, observations, and text reviews. The result of the study shows
\end{abstract}


that the paradigm shift in Islamic education within the Lampung indigenous people was caused by several factors, namely internal factors and external factors. Among the internal factors, the dominance of the parent's mindset is the most significant for the direction shift of education for the Lampung indigenous people. In addition, human resources also influence the shift in the direction of Islamic education. Islamic education exists as a main education and sub education. A the external factors, globalization and modernization are the entry points for a paradigm shift in Islamic education for Lampung's indigenous people. Cultural dynamics and social change are challenges for the world of Islamic education. Islamic boarding schools or Islamic educational institutions are assumed to have no relevance to the progress of the age.

Keywords: Paradigm, Islamic Education, and Lampung Indigenous People

\section{A. Introduction}

Lampung's indigenous peoples (hereinafter read; Ulun Lappung), are generally known as followers of the majority of the Islamic religion. ${ }^{1}$ The belief and determination of Lampung's indigenous people towards Islam has been ingrained, so that in their midst the expression "there is no religion other than Islam".2 This is what then indirectly colors the style and characteristics of the selection of educational institutions for their children. Early on, children have been introduced and taught about the knowledge of Islamic teachings, both from the family environment and from the surrounding community environment.

The choice of Islamic education seems to be the main focus, so parents have a tendency to send their children to religious education institutions. The goal is very simple, so that their generation can recite, understand and know the knowledge of Islam, so that their children and grandchildren can practice the teachings of Islam. ${ }^{3}$ However, this phenomenon lasted from the 1960s to the late 1990s, in the midst of the Lampung indigenous people studying andreligion - for pursuingUlun Lappung it had become an "obligation" and "necessity". Thus, ulun tuho (read; parents) prefer a

${ }^{1}$ Hampir tidak dapat ditemukan masyarakat adat Lampung yang memeluk selain agama Islam. Bagi masyarakat adat Lampung memeluk selain agama Islam adalah cepalo atau aib bagi keluarga besar mereka. Hasil wawancara dengan beberapa tokoh masyarakat adat Lampung yang ada di Kabupaten Lampung Timur, Lampung Tengah, Tanggamus, Pesawaran, Pesisir Barat dan Lampung Utara.

${ }^{2}$ Erwinto, Wawancara dengan salah satu tokoh adat masyarakat Lampung di Kecamatan Sungkai Utara kabupaten Lampung Utara, tanggal 04 Juli 2018

${ }^{3}$ Wawancara dengan KH. Mun'im tanggal 21 Juli 2018 di Way Lima Kabupaten Pesawaran 
religious education institution for their children, both private and public such as in madrasa ibtidaiyah (MI), Madrasah Tsanawiyah (MTs), Madrasah Aliyah (MA), Islamic Higher Education . In fact, it is not uncommon for parents to shelter their children in their homes and in Islamic boarding schools. ${ }^{4}$

The tendency to send children to Islamic education institutions seems to have experienced a slight shift when globalization was present in the midst of Lampung's indigenous people. The impact, there are also parents who shifted the paradigm of thinking in institutions choose anaknya.Masifnya education for the development of globalization in the midst of indigenous Lampung able to deconstruct grip-grip that already exist, including Islamic education. Indirectly - borrowing a term from Mansour Fakih, that globalization is a continuation of colonialism and developmentalism 5 , [5], so that the existence of globalization has broken the chain of what has become the habit of previous parents.

On a practical level, globalization - for Lampung's indigenous people - gives birth to many assumptions if education is only a process to produce graduates who are ready to get a job. In fact, education has a much more valuable value. Ideally, education is able to give birth to values, attitudes and character that are capable. In this position, globalization is welcomed with a tumultuous without considering other aspects, including in matters of religious education.

Choosing an educational institution is a necessity for parents of their children. In the midst of rumors of globalization, choosing educational institutions is something that is not simple. Many educational institutions offer their advantages, such as the advantages of science and technology. Borrowing the term Tilaar, ideally educational institutions are able to become the pioneers of total cultural change that is not only the values of science and technology, but also the nursery of the development of human moral values. ${ }^{6}$ [6] Noting this, education is a complexity of processes that will give birth to superior human beings. Of course, it is not only superior to science and technology, but also must excel in its character and personality (morals).

4 Hasil wawancara dengan beberapa orang tua dan tokoh-tokoh masyarakat adat Lampung yang ada di Kabupaten Lampung Timur, Lampung Tengah, Tanggamus, Pesawaran, Pesisir Barat dan Lampung Utara.

${ }^{5}$ Mansour Fakih, Runtubnya Teori Pembangunan dan Globalisasi, (Yogyakarta: Pustaka Pelajar, 2002), h. 211.

6 HAR. Tilaar, Pendidikan, Kebudayaan, dan Masyarakat Madani Indonesia: Strategi Reformasi Pendidikan Nasional, (Bandung: Rosdakarya, 2002), h. 76 
So far, many people still think that in the learning process and the results obtained - including certainty after their child completes education from an educational institution - have not been able to provide a real answer. So that people assess their absorption in quality schools at the level above which is one of the reasons for them to be willing to send their children to the city in droves. Ironically, even the intended educational institutions are not religious-based schools, but non-religious public schools.

Seeing this, the practice and implementation of education has been colored and even interpreted as a partial paradigm rather than holistic as desired by Islamic education. In fact, paradigmatically, in the context of Islamic education, it must make the Islamic faith as the principle in determining the goals of education, the standard of scientific values and others. In addition, it is alleged that there has been a functional weakness of religious institutions as a result of the less optimal functioning of the family as the first and foremost education.

The emergence of these misperceptions among the Lampung indigenous people, led to the denial of the assumption that the existing Islamic education institutions were not yet fully able to answer the challenges of globalization which were increasingly developing in the remote areas. For this reason, many parents choose public education institutions rather than religious-based education institutions. The shift is increasingly apparent along with the emergence of non-religious or public formal educational institutions, which become "prima donna". Remember, "bargaining power" of graduates from educational institutions Islam is still "low" when compared to other general education.

This kind of casuistic is basically not entirely true. As is known, this problematic problem does not only affect religious education institutions, but also general education institutions. According to Sanaky, the emergence of educational problems that exist in Indonesia can be identified in four main crises, namely concerning issues; quality, relevance, elitism and management. ${ }^{7}$ In other words, not all public education institutions have high quality, and not all religious education institutions have low quality, as is widely assumed by today's society.

Based on the above phenomenon, this article describes the paradigm shift in Islamic education in Lampung's indigenous people. The transition starts from religious-based education to non-religious education. The emergence of a paradigm shift in education on the one hand is

${ }^{7}$ Hujair A. H. Sanaky, "Permasalahan Dan Penataan Pendidikan Islam Menuju Pendidikan Yang Bermutu," El-Tarbawi: Jurnal Pendidikan Islam Vol. 01, No. 1 (2008): h. 84. 
accompanied by the emergence of negative phenomena and social phenomena in the midst of society. The question is whether this has something to do with the paradigm shift in religious education or are there other factors involved? This article is the result offield researchon the direction of changing Islamic education in Lampung indigenous people.

\section{B. Indigenous Peoples in the Globalization}

Lampungof Lampung Province is not only inhabited by indigenous people of Lampung,

8]but is also inhabited by ethnic and other ethnic groups. Until now, it can be found that the existence of other ethnic groups and ethnicities can live side by side. Noting the existence of Lampung residents (Ulun Lappung), basically historically-cultural has been divided into two large communities, namely Pepadun and Saibatin (coastal). ${ }^{9}$ Physically, these two communities showed no sign of significant differences. However, the difference is seen in dialect languages that are often used when communicating.

In communicating, the indigenous people of Pepadun usually use the dialect "O". This accent will be very obvious when pronounced in the original language of Lampung. As for theindigenous Saibatinpeople, they usually use the " $\mathrm{A}$ " dialect 10 , so that in everyday life there are often differences in the use of dialects in communication.

In addition to the language dialect used, the difference also appears in the occupied territories. Theindigenous Saibatinpeople are mostly located in coastal areas - although in reality, diaspora or distribution has occurred at this time - so Saibatinnot always civilians arein the coastal area. Vice versa, it is not always theindigenous people who Pepadun tend to be in areas far from the coast (inland) of Lampung. ${ }^{11}$

8 Penduduk asli Propvinsi Lampung adalah Saibatin dan Pepadun. Lampung merupakan daerah dan kelompok etnik yang menggunakan bahasa Lampung. Secara adat, yang termasuk masyarakat Lampung tidak sebatas yang berada di Propinsi Lampung, tetapi juga masyarakat di daerah Danau Ranau, Muaradua, Komering, hingga Kayu Agung, Propinsi Sumatera Selatan. Lebih lengkap Lihat Hilman Hadikusuma, Masyarakat dan Adat Budaya Lampung, (Bandung: Mandar Maju, 1989), h. 159.

9 Lebih lengkap lihat Ali Imron, Pola Perkawinan Saibatin, (Bandarlampung: Gunung Pesagi, 2002), hlm. 26. lihat juga M. Ikwan, Wujud Arti dan Fungsi Puncak-Puncak Kebudayaan Lama dan Asli Bagi Masyarakat Lampung, (Depdikbud Provinsi Lampung, 1996), h. 31.

${ }^{10}$ Lebih lengkap lihat Safari Daud, dkk., Sejarah Kesultanan Paksi Pak Sekala Brak, (Jakarta: Puslitbang Lektur dan Khazanah Keagamaan Badan Litbang dan Diklat Kementerian Agama RI, Cetakan Pertama 2012), h. 1

${ }^{11}$ Untuk masyarakat adat Saibatin bisanya berkediaman di sepanjang pesisir termasuk adat Krui, Ranau Komering, sampai Kayu Agung. Sementara untuk masyarakat adat Pepadun yang berkediaman di daerah pedalaman Lampung terdiri dari masyarakat adat Abung (Abung Siwo 
Responding to the differences that emerged between the two large communities, Muhammad Aqil Irham by borrowing Nisbet's terminology, had determined the typology of both. In determining the status of someone in the community,traditional typology is Saibatin's more likely to be a status inherited in theascribed status and tradition. Whereas the typology of theindigenous people Pepadun tended to beprinciple of achieved by thestatus and contract, namely the status of a person in the community was more assessed and measured based on their achievements and social contracts at thedensity Perwatinmeeting. 12

Whether we realize it or not, the emergence of typological differences between the two indigenous communities also makes a difference in terms of the governance of their respective justice systems. Thesystem of thecommunity competitivenessSaebatin is more aristocratic, while the people of Pepadun are more democratic in nature. ${ }^{13}$ However, the emergence of these differences does not necessarily make a difference of views on the philosophy of life adopted by indigenous peoples. In principle, each indigenous community is consistent, firm and obedient in holding their traditional values and cultural heritage.

The Lampung community in its original form has its own customary law structure. Traditional ceremonies are generally characterized by the existence of marriage / marriage, which is carried out according to traditional customary procedures in addition to the obligation to carry out / stipulate Islamic law which is assumed to be part of the customary procedure itself.

Lampung indigenous people - both Pepadun and saibatin- together have an orientation that their ancestral heritage is not merely profane. But more than that, the sacredness of these noble values must be implemented and applied and manifested in real life behavior. Noble heritage that has no value contradiction with the norms of religion and ethics, then used as a way of life(wayoflife) Ulun Lampung, which became known as falsah Pesenggiri Piillife.

Piil Pesenggiri is dignity anddignityof Ulun Lampung. In principle, Piil Pesenggiri is a unit that is interconnected and integrated. These values will

Migo), Pubian (Pubian Telu Suku), Menggala/Tulang Bawang (Migow Pak) dan Buai Lima (Marga Bunga Mayang Sungkai). Lebih lengkap lihat dalam Provinsi Lampung Dalam Angka 2018, h. xlvi

${ }^{12}$ Muhammad Aqil Irham, "Lembaga Perwatin Dan Kepunyimbangan Dalam Masyarakat Adat Lampung: Analisis Antropologis", Jurnal Analisis, Volume XIII, Nomor 1, Juni 2013, h. 157

13 Lihat Edward Syah Pernong dalam Lampung Post, 100 Tokoh Terkemuka Lampung, (Bandar Lampung: Lampung Post, 2008), h. 325 
not stand up, if not supported by other principles and fundamentals.14 Further, Fachruddin and Haryadi, emphasized that if someone wants to have self-esteem, then that person must be very clever to respect others $(N$ Met Nyimah/Bepudak Waya), be smart to get along (Nengah Nyappur/Tetengah Tetangah), like working together or mutual cooperation (Sakai Sambaiyan), and being diligent in working to achieving and achieving (Juluk Adek / Khopkhama Delom Bekekhja), that is the principle and that is selfesteem (Bupiil Bupesenggiri). ${ }^{15}$

Today Lampung's indigenous people are no longer able to avoid the emergence of globalization, but those who intentionally apathy or curb themselves away from interaction and communication with globalization. However, this is almost nonexistent and is very rarely found among Lampung's indigenous people. As is known, in almost all the old villages, Lampung's indigenous people have struggled with globalization. This can be seen from the pattern of food, fashion and fun that has become familiar with the Lampung indigenous people.

Based on facts that emerged in the field, for example on the food side, there were many people - especially among children who are currently difficult to recognize the types of traditional (typical) food from the local area. They recognize Kentucky, KFC, burgers and other types of food nowadays, rather than whistle, pindang, sam-sam, sekubal and so on. Not only in terms of food, how to dress in society has also been affected bystyles fashion from western cultures. So that not a few, the young people imitate the way of dressing of public figures.

"We have changed a lot now. In terms of dressing, for example; we often mimic the artists on tv-tv. Let alone in the city, in the villages the children's clothes don't reflect our culture. Even though in the customs of our society, the manner of dress is arranged. Both men and women must close their genitals. The ways that are copied from TV, it is not necessarily suitable with the conditions and environment in which we live. 16

As for fun, the traditional arts of the Lampung indigenous people also began to be contradicted by globalization and modernity. In this section, the community prefers a single organ to be used as entertainment when

14 Ahmad Muzakki, Memperkenalkan Kembali Pendidikan Harmoni Berbasis Kearifan Lokal (Piil Pesenggiri) Pada Masyarakat Adat Lampung, PENAMAS, Vol. 30, No. 3, OktoberDesember 2017, h. 269-270

${ }^{15}$ Fachruddin dan Haryadi, Falsafah Piil Pesenggiri Sebagai Norma Tatakrama Kehidupan Sosial Masyarakat Lampung, (Bandar Lampung: CV. Arian Jaya, 1996), h. 19

${ }^{16}$ Hidayat Sanjaya Gelar Kepalo Margo, Wawancara dilakukan pada tanggal 16 Mei 2018. Pernyataan serupa juga dikemukakan oleh Bapak Humaidi El-Hudri saat wawancara yang dilakukan pada tanggal 18 Agustus 2018 di Sukadana Lampung Timur. 
holding receptions or celebrations, rather than traditional arts, such as single guitars, pepatcur, and others. ${ }^{17}$

The phenomenon of globalization is indeed inevitable, not least for Lampung's indigenous people. Globalization has really spread to various lines and joints of indigenous peoples' lives. For example, many people have switched - and even tend to be more familiar with the new cultures themselves, rather than their local culture. In the end, the culture will erode traditions that have developed in the midst of society. Borrowing Suneki's term, that globalization raises various problems in the field of culture, for example: the loss of the native culture of a region or a country, the erosion of cultural values, a decline in nationalism and patriotism, loss of kinship and mutual cooperation, loss of self-confidence, lifestyle which is not in accordance with our customs. ${ }^{18}$

It is not impossible, if a society has been "hypnotized" by the uproar of globalization, it will have an impact on the other part. Not only in the affected cultural sector, but also the education, socio-economic and political sectors will also be exposed to globalization. For example in the education sector. Parents prefer to send education to non-religious educational institutions, for fear of not being able to compete in the world of work.19

The phenomenon of globalization is indeed inevitable by anyone, except if someone intentionally confines himself or steers clear of interactions and communication with others. It's just that you need to be aware and get a note, besides globalization brings benefits, but also brings madlarat. Therefore, it must be clever to react to it, for example, if the values contained in globalization are positive then it is not wrong to take it, otherwise if it is indeed negative then it must be able to contain it.

\section{Shifting the Paradigm of Islamic Education in Lampung Indigenous Peoples: An Approach Through Thought of Thomas S. Kuhn}

Talking about a "paradigm shift", of course can not be separated from a character named Thomas Kuhn. The emergence of the idea of "paradigm", basically as an attempt to assert if the scientific theory is not only on a series of theoretical principles, but it also includes theworldview. Basically, according to Kuhn, theoretically the mention of paradigms is not different from the term worldview, although it should be realized if in fact Kuhn himself does not have a strong foothold in the definition he is promoting. ${ }^{20}$

\footnotetext{
${ }^{17}$ Ridwan Wawancara dilakukan pada tanggal 21 Juli 2018 di Kabupaten Pesawaran

18 Sri Suneki, Dampak Globalisasi Terhadap Eksistensi Budaya Daerah, Jurnal Ilmiab CIVIS, Vol. II, No 1, Januari 2012, h. 309

${ }^{19}$ Wawancara dengan Syaripudin Basar pada tanggal 20 Oktober 2018

${ }^{20}$ Menurut Heddy Shri Ahimsa-Putra-seorang antropolog budaya, Thomas Kuhn telah berbicara panjang lebar tentang pergantian paradigma, namun sebagaimana telah kita lihat, dia
} 
However, in his magnup opus, Kuhn said, "By choosing it, I mean to suggest that some of the examples of actual practice are examples which include law, theory, application and instrumentation together models from which spring particular coherent traditions of scientifc research".

Referring to the Kuhn statement, then at least, the term paradigm is used in two different purposes. First, the paradigm means that the whole constellation of beliefs, values, techniques, etc. is shared by certain members of society. Second, the paradigm shows a kind of element in these constellations, solving concrete puzzles, which, if used as a model or example, can replace explicit rules as a basis for solving normal science puzzles that are still lagging behind. ${ }^{21}$ However, in essence Kuhn defines paradigm as what is shared by members of a scientific community, and vice versa, a scientific society consists of people who have a common paradigm consensus. 22

Thus, it can be abstracted if the paradigm as a few examples of actual scientific practice is accepted. Examples include law, theory, applications, and instruments that are models that are accepted together and are a source of tradition specifically in scientific research. Based on the description, it can be underlined if the paradigm is a part of the old theory that has been used by scientists as inspiration in scientific practice as a reference to previous research and presented based on the tests and interpretations of scientists based on the scientific method used. For this reason, the output or outcome of the paradigm is used as the overall manifestation of beliefs, laws, theories, values, techniques, and others that have been recognized with members of society.

Furthermore, theoretically, what Kuhn defined as a paradigm in the society of science seems to be similar to the meaning of George Ritzer in

sendiri tidak menjelaskan secara khusus dan rinci tentang apa yang dimaksudnya sebagai paradigma, dan tidak menggunakan konsep tersebut secara konsisten dalam tulisan-tulisannya. Selanjutnya, dijelaskan Heddy, kelalaian Kuhn untuk menjelaskan secara rinci apa yang dimaksudnya sebagai paradigma telah menyulitkan kita untuk menggunakannya sebagai konsep penting guna memahami perkembangan dan mengembangkan ilmu-ilmu sosial-budaya. Sementara itu, tidak banyak ilmuwan sosial-budaya yang menggunakan perspektif Thomas Kuhn untuk memahami perkembangan-perkembangan teori dalam ilmu-ilmu sosial-budaya. Lebih lengkap lihat dalam Heddy Shri Ahimsa-Putra, "Paradigma Ilmu Sosial-Budaya - Sebuah Pandangan -" (Kuliah Umum "Paradigma Penelitian Ilmu-ilmu Humaniora“, Program Studi Linguistik, Sekolah Pascasarjana, Universitas Pendidikan Indonesia, Bandung, Desember 2009), h. 1.

${ }^{21}$ Thomas S. Kuhn, The Structure of Scientific Revolution, Second Edition, (Chicago: University of Chicago Press, 1996), h. 175.

${ }^{22}$ Apa yang disebut Kuhn sebagai masyarakat sains adalah mereka yang terdiri atas pemraktek spesialisasi sains. Lihat dalam Kuhn, h. 176-177. 
interpreting the paradigm in general. As quoted by Nurkhalis, Ritzer said that "paradigm is a way of approaching the investigation of an object or starting point in expressing points of view, formulation of a theory,designing simple questions or reflections". In this way, in the end "paradigm can be formulated as the whole belief system, values and techniques used jointly by the scientific community group". 23

Following up on Nurkhalis's line of thought, the term Paradigm is understood to be the same as worldview, general perspective or way of breaking down the complexity (a way to describe complexity). Noting this, then - borrowing the term from Smart, the meaning of the worldview as a belief, feeling and what is contained in the human mind, serves as a motor for sustainability and social-moral change. ${ }^{24}$

Furthermore, Nurkhalis while referring to al-Attas said if the perspective is the same as worldview. According to him, worldview is a human view of the world of reality. However, the emphasis is more on the function of the worldview as a motor of social-moral change, so that worldview is interpreted as a belief system that is integral to the nature of human beings, reality, and the meaning of existence. ${ }^{25}$

Following the worldview as a scientific activity, Alparslan Açikgenç interpreted it as a principle for every human behavior, including scientific activities in it. ${ }^{26}$ In the next stage, according to Alparslan in Nurkhalis, worldview itself generally has five concept structures or views which consist of the structure of concepts about science; universe; human; life; and about moral values. 27

If the paradigm is interpreted as an interpretive framework based on a set of beliefs and views about the world and how it must be understood and studied, then the paradigm as a tool-set is used to formulate something that is built on fundamental problems about what to study, how to conduct

${ }^{23}$ Lihat juga dalam George Ritzer, Sosiologi Pengetahuan Berparadigma Ganda, trans. Alimandan (Jakarta: Rajawali Press, 2004); Nurkhalis, "konstruksi teori paradigma thomas s. Kuhn,” Jurnal Ilmiah Islam Futura 11, no. 2 (February 1, 2012): h. 82-83,.

${ }^{24}$ Ninian Smart, "Worldview: Crosscultural Explorations of Human Beliefs", (New York: Charles Scribner's sons, 1983), lebih lengkap lihat dalam Nurkhalis, "Konstruksi Teori Paradigma Thomas S. Kuhn,” h. 84.

${ }^{25}$ Syed Muhammad Naquib Al-Attas "Opening Address The Worldview of Islam: An Outline”, lebih lengkap lihat dalam Nurkhalis, h. 84.

${ }^{26}$ Alparslan Açikgenç, "The Framework for A History of Islamic Philosophy," AlShajarah, Journal of The International Institute of Islamic Thought and Civilization (ISTAC) Vol 1., no. Nomor 1 \& 2, (n.d.): h. 6.

${ }^{27}$ Alparslan Açikgenç, Scientific Thought And Its Burdens, An Essay in the History and Philosophy of Science", lebih lengkap lihat dalam Nurkhalis, "Konstruksi Teori Paradigma Thomas S. Kuhn," h. 85. 
assessment, and for what the study was done or to what extent it was able to survive (continuous). Paradigms that are conceptualized as worldview in this case are influenced by rules that are deemed true by humans, deemed correct by reality and deemed true by other entities. The truth based on worldview thisis individualistic, so that there are no claims to truth, even truths that are considered objective are basically "permissible agreements" because of the similarity of the worldview. 28

Starting from the abstraction and description of the paradigm as mentioned above, the process of shifting the paradigm of Islamic education to Lampung indigenous people is not something that suddenly comes. This shift occurs through various events and events that afflict the community. Therefore, there are at least a number of popular perspectives that can be used to identify the emergence of factors that are the causes or causes of the paradigm shift in Islamic education in Lampung indigenous people. Broadly speaking, the underlying factors include; trauma to past history, weakening of existing human resources (HR), the demands of the times.

\section{Globalization and Modernization: The Entrance to the Shift in the Paradigm of Islamic Education}

The shift in the paradigm of Islamic education in Lampung's indigenous people is the result of various touches and dialectics between the emergence of modernization and globalization. This is compounded by the emergence of a space of social, political and cultural reality which is increasingly squeezing their existence. The shift in the paradigm of Islamic education that occurred in the Lampung traditional community resulted in the emergence of many new phenomena in the midst of society, such as juvenile delinquency and others. "We used to see, if the school in a religious education institution could not become an employee (read cannot work). So that we better educate our children in public schools. ${ }^{29}$

Meanwhile, the educational paradigm shift of the Lampung indigenous people was also recognized by one of Lampung's academics who was also the son of the Way Kanan area, Prof. Syaripudin Basyar, M.Ag. According to him, the decreasing interest of the sons of Lampung who chose education in Islamic religious institutions, apart from being related to human resources (HR), was also motivated by the irregularities in the system of Islamic boarding schools or madrasas. Exemplified by him, about Pondok Darussalam. In Lampung there were large and advanced

${ }^{28}$ Nurkhalis, "Konstruksi teori paradigma thomas s. Kuhn," Jurnal Ilmiah Islam Futura 11, no. 2 (February 1, 2012): h. 85.

${ }^{29}$ Ridwan, Wawancara di lakukan di Way Lima Kabupaten Pesawaran pada tanggal 21 Juli 2018. 
Islamic boarding schools, but because they were not accompanied by cadre education and management eventually stagnated and did not develop. On the one hand, transmission of power is not going well. ${ }^{30}$

Furthermore, Syaripudin stated, Lampung's indigenous people viewed Islamic education institutions as unbalanced, even the pattern of education still appeared as a model instrument as a vehicle for the socialization and legitimacy of madzhab. So that to arouse Islamic education institutions from long sleep many things must be done, including fertilizing the reasoning power of Islamic education institutions. ${ }^{31}$

Based on the description above, it can be said that the shift in Islamic education in the midst of Lampung's indigenous people was due to the wave of reality of modernization that hit the wider community. Cultural dynamics and social change are challenges to the world of Islamic education. Social change and the retreat of religious traditions will become more complex as global trends will embrace the same dysfunction. Islamic boarding schools or Islamic educational institutions are assumed to have no relevance to the progress of the age. The emergence of the power of globalization has been predicted by Nawaz, that the paradigmshiftsthat occur in the midst of society are influenced by two factors, namely globalization and digital revolution. ${ }^{32}$

The trend downwardin choosing Islamic education institutions is due to the emergence ofperspectives minor on people with religious education. In other words, there is a kind of excessive suspicion about the rise of Islamic education. So this has an impact on parents who do not want to take risks with Islamic education.

"In the era of 80, 90 to 2000, why did theoccur trend downwardevenly. All of that is because this country does have a slightly minor perspective on people with religious education, or there is excessive suspicion of the rise of Islamic education. So parents don't want to risk their children entering Islamic boarding schools, because people are afraid that in the future they will not work and so forth ".33 Lampung

${ }^{30}$ Syaripudin Basyar, Wawancara dilakukan pada tanggal 20 Oktober 2018 di Bandar

31 Syaripudin Basyar Wawancara dilakukan pada tanggal 20 Oktober 2018 di Bandar Lampung

${ }^{32}$ Allah Nawaz and Muhammad Zubair Khan, "Implications of the Shifting Paradigms in eLearning for Developing Countries like Pakistan," Global Journal of Management and Business Research (USA) Vol. 12, no. Issue 6 (March 2012): h. 46.

33 Wawancara dengan Syaripudin Basyar-salah satu narasumbar focus group discussion (FGD) dalam penelitian ini pada tanggal 20 Oktober 2018 
This condition is one reason, why parents prefer educational institutions - from religious-based schools (madrasas) to general schools. This has become a trend for Lampung's indigenous people from 1980 to 2005. Other than that, explained by Syaripudin Basar, that many parents still think that Islamic education is only as modest. No more than that. Islamic education is not used as a basic education or main education, but instead becomes a sub education. So that religious education is only seen as ordinary and not important in its nature. "Well, there are also those in Lampung like this. The important thing is school children. It is not important for the school to enter. Parents are more likely to only provide fees for their children to continue their education. ${ }^{34}$

However, according to Syaripudin, the trend of shifting Islamic education does not apply to parents or indigenous people who have high mobility and people who have strong religious traditions. Suppose the Lampung indigenous people are growing and developing in the midst of Islamic religious mass organizations, both Nahdlatul Ulama (NU) or Muhammadiyah. Parents who are active in a religious organization have their own perspective. Usually they think very progressively, so that Islamic education is the main target and goal, or what is termed playing education. What is clear is that they will carefully consider and plan the education pattern for their children.

"So it is not surprising that in the past, many parents - especially from the Lampung indigenous people who sent their children to the madrasa, not even a few parents sent their children to Islamic boarding schools, both in Java and those in Lampung" 35

So, parents are a major milestone in designing the education of their children. The trick is to go home or send their children to the madrasa. In a broader spectrum, the aim of sending children to Islamic education institutions is to uphold moral education for their generation. For this, we must be vigilant, at least moral enforcement must be on the agenda and should not be ruled out. The weakening of morals will cause various multidimensional crises in the midst of society.

Parents are the dominant and central factor in choosing educational institutions for their children, also acknowledged by community members in Tanjung Kerta Village, Way Lima, Pesawaran Regency. According to some community leaders, choosing a school for their children is the responsibility of parents. In Tanjungkerta Village there have been interesting habits from parents in choosing religious education institutions.

34 Wawancara dengan Syaripudin Basyar-salah satu narasumbar focus group discussion (FGD) dalam penelitian ini pada tanggal 20 Oktober 2018.

35 Wawancara dengan Syaripudin Basyar pada tanggal 20 Oktober 2018. 
Many parents send their children to study Islam in Makkah and Madinah. But now, these habits have been eroded by the times and the traces are gone.

For example, in the Way Lima area there is KH. Arsyad - a scholar who studied Islam for decades in Makkah. After returning from Makkah, KH. Arsyad founded Islamic Boarding Schools in Way Lima called Alfalah. In the 1940s the boarding school was very well known to the Palembang area and its surroundings, so that many of the children living in the Al-Falah Islamic Boarding School. The existence of Al-Falah hut is one of the pesantren which was founded by native Lampung scholars in Tanjung Kerta Village, Way Lima, Pesawaran. However, after the death of his guardian, namely $\mathrm{KH}$. Arsyad, the hut gradually did not develop, even now the hut was "extinct", because no one continued the leadership of his boarding school.Ghirah sent her children to Islamic education institutions which were very high at that time. This was also acknowledged by $\mathrm{KH}$. Mun'im, one of the residents in Way Lima who has educational products from Arabia. "We used to be like competing to study religion, so our parents learned to get to the source". 36

Based on the description above, it can be obtained if the weakening ghirah of parents against children Islamic education became one of the causes of Islamic education paradigm shift that is in the midst of indigenous peoples. Awareness of the importance of an Islamic education for their children, as happened in the past, cannot be continued by the next generation. In this process the researchers see that there has been a weakening in the human. Ideally, what their parents have pioneered must be increased. In one way, namely choosing an educational institution that is in accordance with what is expected and desired by its predecessors. At the very least, parents choose a lembanga education that is in line or linear with their parents' pilot. In other words, the parent's mindset is one of the factors that influences the paradigm shift in Islamic education for Lampung's indigenous people. If parents think about education, then education for their children is a priority that must be implemented.

Furthermore, other internal factors that also influence the paradigm shift are the weak quality of human resources (HR) from the madrasa manager or boarding school.

"In my opinion, the weakness is not only in the existing human resources, but the weaknesses of the pesantren were not accompanied by the cadre character education of their management, so that the transmission

36 Wawancara dengan KH. Mun'im tanggal 21 Juli 2018 di Way Lima Kabupaten Pesawaran. 
of power did not go smoothly, finally what happened was not just a struggle. this." 37

The emergence of weaknesses in the field of human resources (HR) has a significant impact on the progress of religious education institutions managed. Results that are not good from the management will be known by the wider community, so they prefer schools that have their own superiority. In fact, when we talk about the educational paradigm, the overall view underlying the design of an education system[38] must be considered in all its aspects.

\section{E. Conclusion}

Based on the discussion that has been done in the previous section, that the shift in the paradigm of Islamic education that occurred in Lampung indigenous people was caused by several factors, namely internal factors and external factors.

On internal factors; the dominance of the parent's mindset is one of the causes for the shift in the direction of education for the Lampung indigenous people. Furthermore, human resources also contribute to influencing shifts in the direction of Islamic education. In this section, there is Islamic education that becomes a main education and there is one that becomes a sub education. For parents who think of Islamic education as mind education, he will encourage their children to continue to religiousbased schools. But for parents who are thinking of sub-education, it is not toothink about the basic to school. Next is the external factor (eksteren). In this section globalization and modernization are the entry points for the paradigm shift in Islamic education for Lampung indigenous people. Cultural dynamics and social change are challenges for the world of Islamic education. Islamic boarding schools or Islamic educational institutions are assumed to have no relevance to the progress of the age.

\section{REFERENCES}

Alparslan Açikgenç, "The Framework for A History of Islamic Philosophy," Al-Shajarah, Journal of The International Institute of Islamic Thought and Civilization (ISTAC) Vol 1., no. Nomor 1 \& 2, (n.d.).

Ahmad Muzakki, "Memperkenalkan Kembali Pendidikan Harmoni

Berbasis Kearifan Lokal (Piil Pesenggiri) Pada Masyarakat Adat Lampung", PENAMAS, Vol. 30, No. 3, Oktober-Desember 2017.

${ }^{37}$ Wawancara dengan Syaripudin Basar pada tanggal 20 Oktober 2018 
Ali Imron, Pola Perkawinan Saibatin, Bandarlampung: Gunung Pesagi, 2002 Allah Nawaz and Muhammad Zubair Khan, "Implications of the Shifting Paradigms in eLearning for Developing Countries like Pakistan," Global Journal of Management and Business Research (USA) Vol. 12, no. Issue 6 (March 2012).

Baron and Sukidin, Metode Penelitian Kualitatif Perspektif Mikro, Surabaya: Penerbit Insan Cendekia, 2002.

Bambang Sunggono, Metodologi Penelitian Hukum, Jakarta: PT. Raja Grafindo, 1998.

Edward Syah Pernong dalam Lampung Post, 100 Tokoh Terkemuka Lampung, Bandar Lampung: Lampung Post, 2008.

Fachruddin dan Haryadi, Falsafah Piil Pesenggiri Sebagai Norma Tatakrama Kehidupan Sosial Masyarakat Lampung, Bandar Lampung: CV. Arian Jaya, 1996.

George Ritzer, Sosiologi Pengetahuan Berparadigma Ganda, trans. Alimandan, Jakarta: Rajawali Press, 2004.

Hamam Nasrudin, Humanisme Religius Sebagai Paradigma Pendidikan Islam (Tinjauan Filosofs Atas Pemikiran Abdurrahman Mas'ud), Semarang: IAIN Walisongo, 2008.

Heddy Shri Ahimsa-Putra, "Paradigma Ilmu Sosial-Budaya - Sebuah Pandangan -" (Kuliah Umum "Paradigma Penelitian Ilmu-ilmu Humaniora", Program Studi Linguistik, Sekolah Pascasarjana, Universitas Pendidikan Indonesia, Bandung, Desember 2009.

Hidayat Sanjaya Gelar Kepalo Margo, Wawancara dilakukan pada tanggal 16 Mei 2018.

Hilman Hadikusuma, Masyarakat dan Adat Budaya Lampung, Bandung: Mandar Maju, 1989.

Humaidi El-Hudri, Wawancara yang dilakukan pada tanggal 18 Agustus 2018.

Hujair A. H. Sanaky, "Permasalahan Dan Penataan Pendidikan Islam Menuju Pendidikan Yang Bermutu," El-Tarbawi: Jurnal Pendidikan Islam, Vol. 01, No. 1 (2008).

Hadari Nawawi, Metode Penelitian Sosial , Yogyakarta: UGM Press, 1986.

HAR. Tilaar, Pendidikan, Kebudayaan, dan Masyarakat Madani Indonesia: Strategi Reformasi Pendidikan Nasional, Bandung: Rosdakarya, 2002

Lexy. J. Moleong, Metodologi Penelitian Kualitatif, Bandung: Remaja Rosdakarya, 2000

Mansour Fakih, Runtuhnya Teori Pembangunan dan Globalisasi, Yogyakarta: Pustaka Pelajar, 2002.

M. Ikwan, Wujud Arti dan Fungsi Puncak-Puncak Kebudayaan Lama dan Asli Bagi Masyarakat Lampung, Depdikbud Provinsi Lampung, 1996. 
Muhammad Aqil Irham, "Lembaga Perwatin Dan Kepunyimbangan Dalam Masyarakat Adat Lampung: Analisis Antropologis", Jurnal Analisis, Volume XIII, Nomor 1, Juni.

Mun'im, wawancara dengan tanggal 21 Juli 2018 di Way Lima Kabupaten Pesawaran.

Nurkhalis, "Konstruksi teori paradigma thomas s. Kuhn," Jurnal Ilmiah Islam Futura, no. 2 (February 1, 2012).

Ninian Smart, "Worldview: Crosscultural Explorations of Human Beliefs", New York: Charles Scribner's sons, 1983.

Provinsi Lampung Dalam Angka 2018.

Ridwan, Wawancara dilakukan pada tanggal 21 Juli 2018 di Kabupaten Pesawaran

Robert Bogdan, Introduction to Qualitative Research Methods, trans. Arief Furqon Surabaya: Usaha Nasional, 1992.

Safari Daud, dkk.,Sejarah Kesultanan Paksi Pak Sekala Brak, Jakarta: Puslitbang Lektur dan Khazanah Keagamaan Badan Litbang dan Diklat Kementerian Agama RI, Cetakan Pertama 2012.

Sri Suneki, "Dampak Globalisasi Terhadap Eksistensi Budaya Daerah", Jurnal Ilmiah CIVIS, Vol. II, No 1, Januari 2012.

Syaripudin Basar, Wawancara dilakukan pada tanggal 20 Oktober 2018 di Bandar Lampung.

Thomas S. Kuhn, The Structure of Scientific Revolution, Second Edition, Chicago: University of Chicago Press, 1996. 
134 | AKADEMIKA, Vol. 24, No. 01 January - June 2019 